\title{
PLIOMETRIA ŞI CALISTENIA - METODE DE ANTRENAMENT FIZIC SPECIFICE PREGĂTIRII FIZICE A MILITARILOR
}

\author{
PLYOMETRICS AND CALISTHENICS - \\ PHYSICAL TRAINING METHODS \\ SPECIFIC TO THE PHYSICAL TRAINING OF THE MILITARY
}

\author{
Lt.col.instr.sup.dr. George-Florin BĂIŢAN*
}

\begin{abstract}
Pregătirea fizică a militarilor trebuie să fie una extrem de dură, deoarece aceasta constituie un suport pentru programele de instruire din armată. Mai mult decât atât, trebuie să-i pregătească pe militari pentru ca aceștia să facă față oricărei situații pe care ar putea-o întâlni pe câmpul de luptă: de la escaladarea unui perete înalt de 3 metri, sub focul inamicului, până la alergarea în teren variat, având în spate o raniță de $30 \mathrm{~kg}$ și în mâini armamentul individual din dotare. În plus, menținerea sau îmbunătățirea performanței fizice a militarilor profesioniş̦ti în diferite medii militare este crucială pentru pregătirea militară generală. Când începem un program de antrenament specific mediului militar, avem siguranța că suntem pe drumul cel mai rapid către obținerea unor rezultate serioase. Militarii vor deveni mai puternici, cu o mare forță fizică, având o constituție fizică robustă şi armonioasă. În acest articol, vom prezenta pe scurt două dintre metodele de antrenament fizic specifice instruirii militarilor (pliometria și calistenia), pe care specialiștii în educație fizică militară ar trebui să le utilizeze permanent, pentru ca luptătorii să atingă un nivel superior al pregătirii fizice.
\end{abstract}

The physical training of the military must be extremely hard, as it is a support for military training programs. Moreover, it must prepare the military to deal with any situation they may encounter on the battlefield: from climbing a 3-meter-high wall under enemy fire to running on the varied ground, with a $30 \mathrm{~kg}$ backpack and individual weapons in his hands. In addition, maintaining or improving the physical performance of professional military personnel in various military settings is crucial to general military training. When we start a military-specific training program, we are confident that we are on the fastest track to serious results. The military will become stronger, with great physical strength, having a robust and harmonious physical constitution. In this article, we will briefly present two of the physical training methods specific to military training (plyometrics and calisthenics), which military physical education specialists should use on a permanent basis, so that fighters reach a higher level of physical training.

Cuvinte-cheie: pliometrie; calistenie; pregătire fizică; antrenament; educație fizică militară; exerciții fizice.

Keywords: plyometrics; calisthenics; physical trening; trening; military physical education; physical exercises.

Pliometria este un termen care nu se găsește în Dicționarul explicativ al limbii române, dar acesta este foarte utilizat în rândul sportivilor profesioniști sau pasionaţilor de fitness. Deși termenul de pliometrie este relativ nou, conceptele de bază sunt vechi. El provine din cuvântul englezesc "plyometrics"1, inventat, în anul 1975, de către antrenorul de atletism Fred Wilt, după ce, la un concurs, i-a observat pe sportivii sovietici care executau un program de încălzire, alcătuit din diverse tipuri de sărituri,

\section{*Academia Tehnică Militară „Ferdinand I” \\ e-mail: baitan_george_florin@yahoo.com}

aceștia câștigând, la finalul respectivei competiții, numeroase medalii. Colaborând cu expertul în biomecanică dr. Michael Yessis și traducând din limba rusă cercetările realizate de profesorul Yuri Verhoshansky ${ }^{2}$ (considerat inventatorul antrenamentului pliometric, cercetătorul rus a fost o figură proeminentă în domeniul antrenamentului forței explozive şi unul dintre cei mai mari experți în teoria antrenamentului sportiv, ale cărui idei au fost, ulterior, implementate și extinse), cei doi americani au introdus acest concept în Statele Unite, pentru a transmite aceste informații și antrenorilor americani $^{3}$.

Calistenia este o metodă de antrenament fizic care folosește forța gravitațională și greutatea 
corporală pentru a crește nivelul de pregătire fizică a militarilor. Termenul „calistenic” provine din cuvintele grecești „kalos”, care se traduce prin frumusețe (pentru a sublinia plăcerea estetică ce derivă din perfecțiunea corpului uman, frumusețea pe care o are corpul în mișcare) și „stenos", care exprimă tăria, puterea mentală, curajul și determinarea. Este artadea folosigreutateacorporală ca rezistență pentru dezvoltarea fizicului.

Timp de sute de ani, calistenia a fost principala modalitate prin care oamenii își îmbunătățeau și își mențineau condiția fizică. Chiar dacă termenul era folosit încă din Antichitate, pentru a descrie una dintre metodele de menținere a sănătății, sau chiar dacă metoda a fost folosită ca sursă principală de pregătire fizică a soldaților, iar mai apoi (în secolul al XIX-lea), inclusă în diverse cursuri/programe de educație fizică pentru femei ori într-o ramură a gimnasticii, primele programe de calistenie au apărut prin anii '60 în cadrul forțelor militare aeriene canadiene, contribuind la lansarea culturii moderne a fitness-ului.

În cadrul ședințelor de educație fizică militară desfășurate în unităţile militare, specialiștii în domeniu care conduc activitatea efectuează adesea calistenie cu subunitățile de militari, ca o metodă de antrenament fizic sincronizat pentru a crește coeziunea grupului și pentru a educa militarii în spiritul disciplinei. În plus, două dintre exercițiile de calistenie (flotările și abdomenele) sunt folosite ca probe de evaluare în cadrul verificărilor semestriale ale nivelului de pregătire fizică a cadrelor militare.

\section{Pliometria - antrenamentul prin sărituri}

Pliometria este definită ca fiind o mișcare executată rapid și cu forță, care implică o preîntindere a mușchiului, activând astfel mecanismul de întindere-scurtare a acestuia.

Antrenamentul pliometric, denumit pe scurt „pliometrie”, este o modalitate de antrenament care cere adesea militarilor să sară. De aceea pliometria este de multe ori numită antrenament prin sărituri (sau ,antrenament de şoc"), deoarece o mare parte a exerciţiilor pliometrice se bazează pe tehnica săriturilor (de exemplu: genuflexiuni cu săritură, sărituri de coardă, sărituri cu întoarcere la $180^{\circ}$, sărituri pe platformă, exerciţiul "burpees" etc.). Este o tehnică ce poate fi practicată în mai multe moduri, de aceea este important de reținut că pliometria nu înseamnă doar sărituri, ci și activităţi care necesită mișcări explozive (de exemplu: aruncarea mingii medicinale, sprinturi, diverse tipuri de flotări etc.).

Exercițiile pliometrice sunt acelea care permit mușchilor să efectueze și să dezvolte mișcări intense și rapide în cel mai scurt timp posibil, cu cea mai mare putere și forță. După realizarea unei sărituri, mușchii sunt solicitați de fiecare dată când se atinge solul, lucru care îi conferă următoarei sărituri o putere și mai mare. Această combinație între întinderea și scurtarea/contractarea muşchilor duce la o mai bună tonifiere a corpului. Acest ciclu face ca, la început, mușchiul să sufere o întindere (activare excentrică) și apoi să se contracte (activare concentrică). Mișcările care urmează acest model determină contractarea mușchilor, implicând o forță și o putere mult mai mare ${ }^{4}$.

Incluse în programele de antrenament ale militarilor și efectuate în mod sistematic, exercițiile pliometrice îmbunătățesc randamentul fizic al acestora, dar, în plus, au multe alte avantaje, precum:

- cresc agilitatea corpului. Ne referim la ușurința cu care militarii execută mișcările și la abilitatea acestora de a se mișca rapid, ca urmare a faptului că exerciţiile pliometrice antrenează muşchii principali ai membrelor inferioare, generând o explozivitate care determină efectuarea unei mișcări specifice. Pe câmpul de luptă, agilitatea face diferența dintre o căzătură sau doar o simplă împiedicare ori dezechilibrare;

- îmbunătățesc sănătatea cardiovasculară. Antrenamentele fizice care conțin exerciții pliometrice sunt considerate antrenamente cardio, deoarece sunt solicitate toate grupele musculare principale din corp. Acest lucru, împreună cu diversificarea intensității și a vitezei de execuţie a fiecărei mișcări, provoacă o frecvență cardiacă asemănătoare celei din timpul alergării sau vâslitului;

- dezvoltă propriocepția. Propriocepția este o componentă importantă a echilibrului, coordonării și agilității, fiind necesară efectuării în siguranță a exercițiilor pliometrice. Aceasta se referă la orientarea corpului și a mișcărilor militarilor în spaţiu, în relație cu alte obiecte din jur, la capacitatea mușchilor de a se contracta și de a se relaxa pentru a stabiliza corpul, în funcție de situația dată. $\mathrm{Cu}$ această conexiune consolidată și antrenată corespunzător, militarii dobândesc o stabilitate mai bună și un control ridicat asupra propriului corp. Incluzând exerciţiile pliometrice în programul de 
antrenament al militarilor, aceștia vor învăța cum să se miște mai eficient, vor dezvolta o mai bună conștientizare a locului în care se află, îmbunătățind în același timp și viteza de reacție ${ }^{5}$

- diversifică antrenamentele atunci când se dezvoltă o rutină în antrenament. Organismul militarului se adaptează rapid la stresul și la stimulii la care este supus, iar dacă nu se continuă provocarea lui în noi moduri, atunci performanțele fizice vor deveni statice și neschimbătoare. Introducerea acestor noi exerciții pliometrice este excelentă, deoarece reușește să păstreze mintea ocupată și corpul într-o stare de agilitate;

- crește efectul anabolic care constă în creșterea masei și forței musculare. Introducerea în programul de antrenament săptămânal al militarilor a exercițiilor pliometrice, în momentul în care creșterea musculară a încetinit și antrenamentul obișnuit de forță nu aduce rezultatele scontate, va ajuta la depășirea stagnării cauzate de adaptarea organismului, deoarece încărcătura explozivă va afecta uşor creșterea musculară. Musculatura va fi mai tonifiată, puterea întregului corp se va îmbunătăți, iar masa musculară va crește. În același timp, nu este recomandat să faci aceste exerciţii pliometrice în fiecare zi, deoarece, după o sesiune de mișcări explozive, mușchii corpului au nevoie de o pauză pentru a se reface; ${ }^{6}$

- previn apariția unor forme de accidentare. Practicând constant astfel de exerciții, corpul va învăța să răspundă la diferite niveluri de impact. Având în vedere faptul că săriturile repetate vor provoca un impact continuu asupra articulațiilor, trebuie să ținem cont de principiul progresivitătii și trebuie să se folosească o încălțăminte sport adecvată, care să amortizeze impactul cu solul (pentru ca gleznele și genunchii să sufere mai puțin). Musculatura militarilor se va dezvolta, rezistența şi elasticitatea tendoanelor şi a ligamentelor va crește, fapt care va duce la reducerea probabilității de apariție a accidentărilor în timpul desfășurării unor acțiuni militare (întinderi sau rupturi musculare, microtraumatisme sau traumatisme ale ligamentelor și tendoanelor);

- favorizează pierderea rapidă în greutate. Exercițiile pliometrice activează aproape toate grupele musculare, fiind foarte intense și necesitând un consum mare de energie (arzându-se o cantitate mare de calorii într-o ședință de antrenament), deci reprezintă un instrument excelent pentru pierderea în greutate și pentru definirea masei musculare. Antrenamentele pliometrice sunt considerate ca cel mai eficient mod de a arde grăsimile din partea inferioară a trunchiului și din zona membrelor inferioare (pentru partea superioară a corpului, trebuie utilizate exercițiile fizice care folosesc mingea medicinală);

- imbunătățesc echilibrul și coordonarea, dacă exerciţiile sunt executate cu o bună concentrare și atenție. La început, aceste exerciții pot părea dificile pentru militari, însă, lucrând constant, ele vor începe să devină mult mai ușor de făcut, iar mișcările vor deveni mai eficiente și mai agile, moment în care, sub îndrumarea specialistului în educaţie fizică militară, este recomandat să se crească gradual numărul de repetări;

- permit desfãşurarea antrenamentului fără a avea nevoie de echipament suplimentar. Exercițiile pliometrice sunt o alternativă excelentă, dar și distractivă, la antrenamentele cu greutăţi. Pentru a efectua exerciţii pliometrice, militarii au nevoie doar de propria lor greutate corporală și de un spațiu liber în care aceștia să se poată mișca. Folosind echipament minim, un antrenament pliometric cu adevărat eficient se poate face oriunde, în doar 15-30 de minute (inclusiv la domiciliu), ceea ce este perfect atunci când timpul avut la dispoziţie este redus. După un timp, pot fi utilizate și diverse greutăți sau o platformă cu trepte pentru executarea săriturilor, dar, la început, pentru majoritatea exercițiilor pliometrice, echipamentul nu este necesar.

Aceste exerciții nu sunt recomandate militarilor care au un nivel al pregătirii fizice scăzut sau sunt în perioada de refacere după o accidentare, deoarece executarea lor necesită un anumit nivel de coordonare, echilibru și forță. Motivul pentru care exercițiile pliometrice sunt destul de populare în rândul militarilor este că acestea permit unui mușchi să atingă forța maximă într-un timp foarte scurt.

Gama extrem de vastă a exercițiilor pliometrice include orice acțiune motrică ce conține sărituri și dinamism. Vom prezenta în continuare cele mai utilizate exerciţii pliometrice de către specialiștii în educaţie fizică militară, care nu necesită folosirea unor echipamente scumpe și pe care le vedem de cele mai multe ori în sălile de fitness. Acestea sunt $^{7}$ :

- genuflexiuni: cu săritură laterală, cu un picior ridicat, frontale, cu împins de la umeri, folosind 
două greutăți kettlebell/bara olimpică, cu haltera sprijinită pe umeri;

- fandări: laterale, înainte, cu săritură, din mers, cu gantere, înapoi din deficit;

- „Burpees” (exerciţiu care cuprinde o flotare, o săritură din poziția culcat facial, cu sprijin pe palme, în sprijin ghemuit și o săritură cu ducerea brațelor sus);

- flotările pliometrice (cu săritură), cu desprinderea palmelor de pe sol. Se pot executa ca variantă și cu bătaie din palme;

- sărituri pe loc: ca „mingea”, într-un picior, de pe un picior pe altul, de pe un picior, cu aterizare pe ambele picioare, $\mathrm{cu}$ ridicarea genunchilor la piept (simultan/alternativ), cu pendularea gambelor înapoi prin atingerea feselor cu călcâiele (simultan/ unilateral), cu forfecare (cunoscute și sub denumirea de „Jumping Jacks” - din poziţia stând - sărituri în depărtat lateral, cu ducerea brațelor sus prin lateral - revenire în poziția inițială), cu bara în spate, cu coarda;

- exercițiul „Plank Jumping Jacks” - din poziția culcat facial cu sprijin pe palme/antebrațe (poziția planșă) - depărtarea și apropierea picioarelor prin salturi;

- sărituri de pe loc: cu aterizare pe „stepper aerobic" sau pe o cutie, în înălțime, cu plecare din poziția ghemuit, cu atingerea unor obiecte mai înalte (cu capul, cu mâna sau piciorul), în lateral, peste anumite obstacole sau pe diverse platforme;

- sărituri în lungime de pe loc: în adâncime, liniare, cu aterizare în groapa cu nisip sau pe saltele, cu aterizare după semne trasate pe sol, peste obstacole de înălțime mică (gărdulețe), de „tipul șotron” (folosind materiale precum: cercuri, scărițe sau chiar desenând pe sol anumite figuri geometrice), balansând o minge medicinală cu ambele mâini, precedată de o săritură jos de pe o cutie, precedată de o săritură înapoi;

- sărituri pe treptele scărilor pe ambele picioare sau într-un picior (pe fiecare treaptă, din două în două trepte etc.) sau sprinturi scurte pe plan înclinat;

- sărituri laterale în zig-zag de pe un picior pe celălalt;

- sărituri pe o platformă (cutie, ladă) din șezut, având gantera la piept (exercițiu dificil, nerecomandat începătorilor, deoarece necesită o bună condiție fizică, mobilitate și coordonare).

După cum se poate observa din aceste exemple de exerciții pliometrice, toate presupun cunoașterea tehnicii de execuție a tuturor fazelor unei sărituri, în special a aterizării (amortizarea șocului, la contactul cu solul, prin mecanismul triplei flexii). Fiind mai intense, aceste tipuri de mișcări vor crește ritmul cardiac, ceea ce înseamnă că se vor arde mai multe calorii, obținându-se astfel un antrenament cardiovascular mai eficient.

Scopul principal al antrenamentului pliometric este de a crește excitabilitatea receptorilor neurologici pentru o reactivitate îmbunătătită a sistemului neuromuscular. Un exerciţiu pliometric cuprinde trei faze, acestea constituind mecanismul de bază al antrenamentului pliometric ${ }^{8}$, astfel:

- faza excentrică (faza de aterizare), care presupune preîncărcarea (energia este stocată) a grupelor musculare agoniste. Forța maximă pe care o poate dezvolta un mușchi este atinsă în timpul unei contracții excentrice rapide;

- faza de amortizare (faza de tranziţie) este reprezentată de timpul scurs dintre cele două faze (excentrică şi concentrică). Acest timp trebuie să fie cât mai scurt posibil, astfel încât energia stocată în timpul fazei excentrice să se disipeze cât mai puțin posibil, pentru a nu reduce efectul pliometric;

- faza concentrică (faza de decolare) folosește energia stocată pentru a crește forța mișcării. Atunci când apare o contracție izotonică concentrică (presupune scurtarea în lungime a mușchiului), imediat după o contracție izotonică excentrică (sau negativă, mușchiul se alungește, readucându-1 la poziția de start), forța generată poate crește dramatic.

Aceste exerciţii pliometrice pot fi integrate, într-o mulțime de modalități, în programele de antrenament pentru dezvoltarea forței la militari, sau se poate crea un circuit (ori un antrenament clasic Tabata), format doar din exerciţii pliometrice, în funcție de obiectivele antrenamentului și de nivelul de pregătire fizică al militarilor. La baza acestei metode de antrenament (metoda şocului), se află principiul progresiei și regula răbdării, deoarece exercitiile pliometrice trebuie efectuate mai mult timp pentru a se vedea rezultatele preconizate ${ }^{9}$. Important este ca exercițiile pliometrice executate să se aproprie cât mai mult de mișcările pe care militarii ar putea să le facă pe câmpul de luptă, pentru a crește considerabil forța și performanța.

Antrenamentul cu greutăți și exercițiile pliometrice pot fi combinate în ședințe complexe de antrenament pentru a dezvolta puterea explozivă. 
Pliometria poate fi combinată cu un antrenament de forță (niciodată cu un antrenament aerob/ cardio), deoarece aceasta este formată din exerciții preponderent anaerobe, așa cum sunt și exercițiile de forță $\breve{~}^{10}$. Inainte de a începe un program de pliometrie, ca o condiție prealabilă, este recomandat ca militarii să fie supuși testelor Klatt ${ }^{11}$, pentru a se evalua, iniţial, gradul de echilibru și de stabilitate al săriturilor. Testele includ mișcările pliometrice de bază, deci dacă acestea nu pot fi realizate, se poate presupune că militarul nu este încă pregătit din punct de vedere fizic pentru un program de pliometrie.

\section{Calistenia - antrenamentul cu greutatea corporală}

La început, calistenia a fost un mod de a promova starea fizică și fiziologică normală a unui organism sănătos, dar, în timp, a evoluat la nivelul unei metode de antrenament care are multe aspecte în comun cu gimnastica. Spre deosebire de aceasta totuși, calistenia poate fi practicată în aer liber (oriunde și oricând), fiind cunoscută și sub denumirea de ,antrenament de stradă”. Este una dintre puținele modalităţi în care se poate construi masa musculară și în care se poate dezvolta puterea fizică, fără a folosi greutăți.

Un lucru bun al calisteniei este acela că nu este nevoie de materiale de ultimă generație pentru a începe un antrenament specific. Majoritatea echipamentelor de care este nevoie se găsesc în aproape toate unităţile militare, și anume: o bară fixă și două bare paralele. Cu timpul, pentru a diversifica exercițiile și pentru a trece la un nivel avansat, se pot achiziţiona câteva benzi elastice pentru fitness (pe diferite niveluri de rezistență) şi un set de inele de gimnastică, concepute pentru cross-training.

Principiile calisteniei au evoluat foarte mult în secolul al XIX-lea, bazându-se pe studiile efectuate în domeniile fiziologiei, anatomiei și mecanicii clasice, iar cele mai mari influențe în realizarea unui antrenament fizic de tip calistenic au venit din metoda suedeză de gimnastică. Aceasta era împărțită în patru părți (gimnastica pedagogică și educațională, gimnastica medicală și ortopedică, gimnastica estetică şi gimnastica militară) şi avea obiective foarte asemănătoare cu calistenia, creată cu scopul de a fi accesibilă tuturor oamenilor, de a îmbunătăţi sănătatea și de a dezvolta armonios corpul. Următoarele principii au fost adoptate pentru a structura calistenia ${ }^{12}$ :

- principiul selecției - se referă la aceea că exercițiile trebuie alese cu atenție, iar seriile de exerciţii efectuate nu trebuie să fie doar o grupare de repetări, executate una după cealaltă, ci și să le dezvolte militarilor capacitatea de a cunoaşte noțiuni legate de educația sanitară și prevenție, de recreere sau de mediul ambiant, natural şi social;

- principiul preciziei - presupune ca exercițiile să fie executate perfect, conform indicațiilor, după primirea celor mai bune explicații privind tehnica corectă de execuție, pentru a atinge agilitatea și suplețea propuse de calistenie;

- principiul totalității - este evidențiat în programul zilnic de antrenament calistenic, care este întocmit astfel încât să producă atât un efect general asupra maselor musculare mari, cât şi să educe o eleganță/un echilibru în mișcare și o postură corectă (esențială pentru o sănătate bună);

- principiul progresiei - se raportează la intensitatea efortului, care trebuie sporită treptat atât prin numărul de exerciții efectuate, cât și prin creșterea vitezei de execuție și a complexității fiecărui exerciţiu, evitând, în același timp, apariţia unei suprasolicitări excesive;

- principiul adaptării - în care se va ține cont de vârsta, sexul și specialitatea militarilor.

Un studiu realizat, în anul 2017, la o universitate italiană de cercetare a științelor sportului și exercițiului fizic a constatat faptul că antrenamentul de calistenie este o soluție eficientă de antrenament pentru a îmbunătăţi forța, postura și masa corporală, fără a utiliza echipamente majore de antrenament ${ }^{13}$.

Alegerea celor mai bune exerciții de calistenie pe care militarii le pot executa depinde, în primul rând, de nivelul lor de experiență. Cei începători vor trebui să pornească cu elementele de bază, iar cei care s-au antrenat de ceva timp pot trece la exerciții decalistenie complexeşi mai provocatoare. Celemai cunoscute și mai des efectuate exerciții calistenice (fiecare având diverse variante de execuție) sunt: flotările, abdomenele, genuflexiunile, „Burpees”, fandări înainte, planșa/scândura („Plank”), sărituri cu coarda, ridicări pe vârfuri, ,Jumping Jacks”, tracțiunile la bara fixă, flotările la barele paralele, stând pe mâini, hiperextensii lombare, ridicări ale picioarelor din poziția culcat pe spate, urcarea prin răsturnare/îndreptare la bara fixă, atârnat la bara 
fixă, având corpul paralel cu solul, cu faţa în sus/ în jos și cu brațele întinse (,Front/Back lever”), din poziția sprijin la inele - trecere în poziția echer menţinere și revenire, testul de anduranță „Beep” etc.

Calistenia de conlucrare se referă la acele exerciţii calistenice care implică doi sau mai mulți militari care se ajută reciproc pentru a efectua o acțiune motrică. Astfel de exerciții fizice sunt cunoscute și sub denumirea de exerciții cu partener, constând în transportul partenerului sau în executarea unor mișcări cu un grad de dificultate accentuat de greutatea sau de rezistența opusă de partener, fiind folosite și ca o modalitate de dezvoltare a calităților motrice. Un dezavantaj pe care îl au astfel de exerciții este acela că rezistența opusă de către partener este greu de măsurat, în comparație cu aparatele multifuncționale din sălile de fitness, dar, pe de altă parte, ele pot fi efectuate la fel de ușor în aer liber sau într-o sală de sport și sunt suficient de versatile, pentru a permite să fie folosite și în alte scopuri ale antrenamentului decât pur și simplu pentru cel de dezvoltare a forței.

Practicând calistenia, după un timp, se va atinge un punct maxim de creștere musculară, deoarece masa musculară provine din rezistența progresivă, oferită de greutatea propriului corp. Pentru a crește procentul de greutate corporală care trebuie ridicat, e nevoie de creativitate în ceea ce privește creșterea progresivă a dificultăţii, duratei și intensităţii exercițiilor.

Calistenia este modalitatea perfectă de antrenament funcțional al mișcării, deoarece majoritatea exerciţiilor calistenice sunt mișcări musculare compuse, ceea ce înseamnă că, în același timp, lucrează maimultegrupemusculare. Pregătirea funcțională presupune să te antrenezi într-un mod care să îmbunătățească direct modalitatea în care trebuie îndeplinite sarcinile cotidiene sau cerințele fizice specifice câmpului de luptă (Antrenează-te aşa cum vei lupta!). $\mathrm{Cu}$ aceste mișcări funcționale, militarii devin mai puternici și mai flexibili, pierd în greutate și obțin o formă fizică optimă în cel mai natural mod posibil, fără să-și afecteze articulațiile prin sălile de fitness.

Când sunt efectuate incorect sau prea des, antrenamentele de forță absolută (,,se referă la cea mai mare forță pe care o poate genera sistemul neuromuscular în organism prin contracție voluntară maximă" ${ }^{14}$ ), în care se folosesc greutăți prea mari, pot crea unele dezechilibre, care vor pune un stres suplimentar asupra tendoanelor și ligamentelor. Pe de altă parte, calistenia dezvoltă puterea fizică doar proporțional cu sistemul muscular al militarului, cu mișcările lui autentice și naturale, reducând semnificativ acest risc de accidentare care poate apărea. Frumusețea exercițiilor cu greutatea corporală constă în faptul că riscul general de accidentare este redus, iar antrenamentele sunt mai sigure.

Antrenamentul pentru calistenie dezvoltă acele abilități motorii fine care solicită corpul și creierul să lucreze din greu, îmbunătătind astfel conexiunea dintre creier și corp. Aproape toate formele de manifestare a calităților motrice de bază sunt educate la un nivel ridicat într-un corp instruit în arta calisteniei. „Dezvoltarea unor programe de forţă, bazate pe exerciţii considerate calistenice (...) poate conduce la îmbunătăţirea capacităţii de efort a militarilor, precum şi la dezvoltarea de abilităţi fizice necesare unor situaţii din timpul misiunilor - patrulare cu echipament greu, căţărare cu echipament de luptă, înot echipat, transport răniţi”'15.

Prin complexitatea lui, domeniul educației fizice pare să fie unul plin de tendințe și orientări metodologice, precumşi de sfaturi privind revizuirea regimului alimentar sau refacerea capacităţii de efort. Toate aceste aspecte pot provoca confuzie în rândul specialiștilor de educație fizică militară. Foarte asemănătoare și adesea confundate între ele, calistenia și pliometria sunt două metode populare de antrenament fizic, specifice pregătirii fizice a militarilor. $\mathrm{Cu}$ toate acestea, există diferente între ele și este benefic să înțelegem care sunt aceste diferențe, pentru a putea alege tipul de antrenament care se potrivește cel mai bine obiectivelor propuse.

Calistenia și pliometria sunt efectuate fără niciun echipament, folosindu-se, îndeosebi, doar greutatea corporală. Diferența dintre acestea este definită de acțiunea unui obiect care vine în contact cu celălalt, de ,impactul” corpului cu obiectele din mediul înconjurător (podeaua, instalațiile și echipamentele sportive etc.). Calistenia are un impact redus și se concentrează pe mișcările de bază pentru dezvoltarea forței. Pliometria este cu un pas peste aceasta, are un impact ridicat prin încorporarea acestor mișcări de bază cu antrenamentele pentru îmbunătățirea săriturilor și pentru creșterea agilităţii. La început, trebuie să te pregătești, folosind exercițiile calistenice și, 
odată ce te simți confortabil, vei începe să adaugi săriturile și mișcările rapide.

Mișcările calistenice sunt unele fundamentale și construiesc o bază solidă pentru alte exerciții mai avansate. La acest nivel, învățarea formei corecte de execuție și dezvoltarea forței reprezintă obiectivele principale pentru o pregătire fizică generală. Dacă militarii sunt începători, dacă se recuperează după o accidentare sau dacă se întorc la antrenamente după o perioadă mai lungă de pauză, atunci este ideal să înceapă pregătirea fizică din acest punct. De asemenea, cunoașterea modului de efectuare corectă a exercițiilor de bază ajută la prevenirea apariției accidentărilor și a durerilor severe, provocate de deteriorarea fibrelor musculare (febra musculară).

Pliometria este elementul de construcție a pregătirii fizice, care se adaugă peste calistenie, constând în aceea de a face exercițiile de bază mai provocatoare și mai interesante. Un exercițiu calistenic, precum genuflexiunile, poate fi modificat într-unul pliometric, adăugând o săritură, și transformându-lîngenuflexiunicu săritură. Odatăce calistenia este stăpânită, se poate trece la executarea mișcărilor pliometrice avansate, obținând astfel un antrenament mult mai bine definit, deoarece pliometria are avantajul suplimentar de a susține buna functionare a sistemului cardiovascular.

În cele din urmă, pliometria este despre sărituri și despre mișcările explozive care au un consum mare de energie, iar calistenia se concentrează pe tehnica de execuție a mișcărilor de bază. De aceea este indicat să se înceapă cu exercițiile calistenice și să se încorporeze treptat și mișcările pliometrice, pentru a câștiga rapid forță și rezistență.

\section{Concluzii}

A fi în armată înseamnă adesea a fi departe de liniștea și de siguranţa pe care ți le oferă domiciliul, iar, de cele mai multe ori, nu ai acces la toate facilitățile de care dispune o sală de fitness sau o sală de sport. În ciuda faptului că își desfăşoară activitatea în locuri neospitaliere, militarii trebuie să fie și să rămână în formă în permanență. Executarea exercițiilor pliometrice și a celor calistenice nu este condiționată de deținerea vreunui echipament (acestea putând fi efectuate oriunde și oricând), fapt ce le face ideale pentru includerea lor în programele de antrenament fizic ale personalului militar.

Antrenamentul calistenic se pliază perfect pe activitățile zilnice, desfășurate de militari pe terenul de instrucție. În această situație, nu este vorba doar de folosirea greutății corporale pentru a dezvolta calităţile motrice și pentru a crește nivelul de pregătire fizică, ci și de a-i învăța pe militari cum să fie mai agili, coordonați și mai echilibrați în mișcările lor, abilități fizice de care, cu siguranță, vor avea nevoie în situațiile concrete de luptă.

Antrenamentul pliometric oferă metode şi mijloace moderne de dezvoltare a calităţilor motrice ale militarilor. Cunoaşterea cu punctualitate a ce înseamnă pliometria, înțelegerea modului în care trebuie să fie executate corect mişcările pliometrice, precum și respectarea măsurilor de siguranţă pe timpul executării exercițiilor pliometrice vor duce la creșterea nivelului de pregătire fizică a militarilor. Exercițiile pliometrice sunt o excelentă modalitate de a îmbunătăți performanțele atletice ale militarilor și nivelul de pregătire fizică al acestora prin dezvoltarea calităților motrice de bază (forță, viteză, suplețe). Un astfel de antrenament pliometric (care urmărește să reducă decalajul dintre forță și putere) poate fi un adevărat plus pentru orice program de pregătire fizică, dacă acesta este executat corect și dacă este concentrat pe tehnică și precizie. Este evident faptul că antrenamentul pliometric oferă beneficii semnificative militarilor, deoarece majoritatea mișcărilor pe care aceștia le execută, pentru a avea succes în timpul desfășurării unor acțiuni militare, se bazează pe mișcări rapide şi în forță.

Un rezultat favorabil, obținut ca urmare a executării unui antrenament fizic specific pregătirii fizice a militarilor, în care sunt folosite metodele pliometriei și/sau calisteniei, îl reprezintă oferirea unui spațiu pentru ca aceștia să-și dezvolte abilitățile de gândire și să se simtă liberi să-și împărtășească convingerile și părerile personale cu restul camarazilor, precum și cu specialistul în educație fizică militară care conduce activitatea. Armata fiind renumită pentru îndoctrinarea trupelor, astfel ca acestea să rămână disciplinate și ascultătoare și să execute pur și simplu ordinele primite, cred că atât ordinele emise, cât și răspunsurile la acestea ar trebui să fie întotdeauna bine gândite și să contribuie obiectivelor specifice sistemului militar.

Cele două metode de antrenament (pliometric și calistenic) nu ar trebui să fie considerate scopuri în sine, ci părți componente ale unui program general de pregătire fizică (pe lângă dezvoltarea calităţilor motrice, refacerea după efort și o alimentație adecvată). Militarii care posedă niveluri 
adecvate ale calităților fizice vor efectua cu mai mult succes exerciții pliometrice și calistenice. În plus, combinarea acestor tipuri de exerciţii cu altele permite militarilor să optimizeze performanța, indiferent de cerinţele fizice la care sunt supuși sau de activitatea pe care trebuie să o desfășoare.

\section{NOTE:}

1 Plyo - vine din cuvântul grecesc plythein, care înseamnă ,a crește” (plio, în limba greacă, înseamnă „mai mult"), iar metric, înseamnă literalmente ,,a măsura”.

2 http://www.verkhoshansky.com/CVBibliography/ tabid/71/Default.aspx, accesat la 21.10.2021.

3 F. Wilt, M. Yessis, Soviet Theory Technique and Training for Running \& Hurdling, Championship Books, Publisher Stoyles Graphic Services, 1984, p. 92.

$4 \mathrm{https}$ //tiptar.com/ro/what-are-plyometrics-and-howto-include-them-in-your-routine, accesat la 22.10.2021.

$5 \mathrm{https} / /$ proteic.ro/exercitii-pliometrice, accesat la 23.10.2021.

6 https://ro.healthy-food-near-me.com/plyometric-trai ning-the-pros-and-cons-exercises-training-program, accesat la 23.10.2021.

7 G.F. Băițan, Admiterea în instituțiile militare de invățământ din Ministerul Apărării Naționale - probele sportive, Editura Universității Naționale de Apărare „Carol I”, București, 2020, p. 31.

$8 \mathrm{https}$ //www-brianmac-co-uk.translate.goog/plymo. $\mathrm{htm}$ ?_x_tr_sl=en\&_x_tr_tl=ro\&_x_tr_hl=ro\&_x_tr pto $=$ nui,sc, accesat la $24.10 .202 \overline{1}$.

9 T.O. Bompa, C.A. Buzzichelli, Periodizarea: Teoria și metodologia antrenamentului, Lifestyle Publishing, București, 2021, p. 152.

$10 \mathrm{https}: / / w w w . a b c . e s /$ bienestar/fitness/abci-pliometria202006110754_noticia.html, accesat la 23.10.2021.

$11 \mathrm{https}: / /$ enterprisefitnessacademy.com/eclass-2-klatttest-assessment, accesat la 24.10.2021.

$12 \mathrm{https} / / / \mathrm{blogeducacaofisica.com.br/guia-definitivo-}$ calistenia/, accesat la 26.10.2021.

$13 \mathrm{https}: / / w w w . r e s e a r c h g a t e . n e t / p u b l i c a t i o n / 317321$ 468_The_effects_of_a_calisthenics_training_intervention on_posture_strength_and_body_composition, accesat la 25.10.2021.

14 M.C. Istrate, „Forța - calitate motrică cu impact determinant în activitatea militară", Buletinul Universităţii Naţionale de Apărare ,, Carol I” nr. 3, București, 2020, p. 208.

15 G.C. Ciapa, Orientări și oportunități pentru pregătirea fizică a militarilor, Editura Universităţii Naționale de Apărare „Carol I”, București, 2019, p. 54.

\section{BIBLIOGRAFIE}

*** Regulamentul educaţiei fizice militare, Editura Centrului tehnic-editorial al armatei, Bucureşti, 2013.

Băițan G.F., Admiterea în instituțiile militare de învățământ din Ministerul Apărării Naționale probele sportive, Editura Universității Naţionale de Apărare „Carol I”, București, 2020.
Bompa T.O., Buzzichelli C.A., Periodizarea: Teoria și metodologia antrenamentului, Lifestyle Publishing, București, 2021.

Bowman A., Calisthenics Workout: Building Muscle \& Getting Ripped Without a Gym (Simple Bodyweight Exercises to Gain Strength, Size and Balance), Editura Tomas Edwards, 2021.

Ciapa G.C., Orientări și oportunități pentru pregătirea fizică a militarilor, Editura Universităţii Naționale de Apărare „Carol I”, București, 2019.

Goldman J., Calisthenics: Calisthenics Guide: BodyWeight Exercises, Workout Progression and Training to Be Fit, Kindle Edition, 2016.

Istrate M.C., ,Forța - calitate motrică cu impact determinant în activitatea militară”, Buletinul Universităţii Naţionale de Apărare ,, Carol I” nr. 3, București, 2020.

Kalym A., Complete Calisthenics, Second Edition: The Ultimate Guide to Bodyweight Exercise, North Atlantic Books, 2019.

Neagu N., Fundamentele antrenamentului pliometric, Editura Discobolul, București, 2020.

Pelmuş A.D., Dezvoltarea capacității motrice a personalului militar, Editura Centrului tehniceditorial al armatei, București, 2021.

Radcliffe J.C., R. Farentinos, High-Powered Plyometrics, Editura Human Kinetics, 2015.

Wilt F., Yessis M., Soviet Theory Technique and Training for Running \& Hurdling, Championship Books, Publisher Stoyles Graphic Services, 1984.

http://www.verkhoshansky.com/CVBibliogra phy/tabid/71/Default.aspx

https://iptar.com/ro/what-are-plyometricsand-how-to-include-them-in-your-routine

https://proteic.ro/exercitii-pliometrice

https://ro.healthy-food-near-me.com/ plyometric-training-the-pros-and-cons-exercisestraining-program

https://www-brianmac-co-uk.translate.goog/ plymo.htm?_x_tr_sl=en\&_x_tr_tl=ro\&_x_tr_hl= ro\&_x_tr_pto $=$ nui,sc

https://www.abc.es/bienestar/fitness/abci-plio metria-202006110754_noticia.html

https://enterprisefitnessacademy.com/eclass-2-

klatt-test-assessment

https://blogeducacaofisica.com.br/guia-definiti vo-calistenia/

https://www.researchgate.net/publication/31 7321468_The_effects_of_a_calisthenics_training intervention_on_posture_strength_and_body_ composition 